\section{Ripening-induced Chemical and Antioxidant Changes in Bell Peppers as Affected by Harvest Maturity and Postharvest Ethylene Exposure}

\author{
Abbie J. Fox, ${ }^{1}$ David Del Pozo-Insfran, ${ }^{2}$ Joon Hee Lee, ${ }^{2}$ Steven A. \\ Sargent, ${ }^{3}$ and Stephen T. Talcott ${ }^{4}$ \\ University of Florida, Institutefor Food and Agricultural Sciences, Gainesville, \\ FL 32611-0370
}

Additional index words. quality, marketing, phytochemicals, antioxidant capacity

\begin{abstract}
Greenhouse-grown bell pepper (Capsicum annuum L. 'Robusta') were harvested at five stages of maturation (10\% red to full red) in early winter 2002 (Expt. 1) and at two stages $(10 \%$ red and full red) in early Spring 2002 (Expt. 2). The fruit were subsequently stored at $20^{\circ} \mathrm{C}$ in a continuous-flow chamber consisting of either $100 \mu \mathrm{L} \cdot \mathrm{L}^{-1}$ ethylene (balance air) or air-only (control) at $90 \%$ relative humidity (RH). Individual fruit were removed from the chambers upon reaching full red color, and stored at $-30^{\circ} \mathrm{C}$ until physicochemical analyses were conducted. Harvest maturity, and ethylene exposure had no appreciable effect on pulp soluble solids content, total titratable acidity or $\mathrm{pH}$. Exposure to ethylene hastened ripening time compared to the air control but was independent of fruit maturity at harvest. Fruit exposed to ethylene reached full-red color 6.4 days (Expt. 1) and 4 days (Expt. 2) earlier than air-only fruit, respectively. There were no significant phytochemical and antioxidant differences noted for total carotenoids, total ascorbic acid, and soluble phenolics at various maturity stages due to ethylene exposure. Appreciable differences were observed between the two experiments for phytochemicals and antioxidants, as bell peppers from the latter experiment contained at least twice the concentrations of phytochemicals and antioxidant capacity as those from the first experiment. Differences in these parameters between experiments were attributed to environmental factors such as average temperature, day length, and light intensity. Ethylene was demonstrated to be an effective postharvest treatment for accelerating color change in this bell pepper cultivar, permitting earlier harvest without altering phytochemical synthesis rates.
\end{abstract}

Bell pepper (Capsicum annuum L.) is a nonpungent fruit that is valued for color, flavor, and nutritional attributes including ascorbic acid, polyphenolics, and various carotenoids. In 2002, U.S. production totaled about $\$ 500$ million, with Florida being the predominant supplier of fresh-market, bell peppers during the fall, winter and spring seasons, and California being the major summer supplier (NASS, 2004). Practically all green peppers are field grown and for fresh-market consumption are manually harvested on multiple occasions throughout the growing season. Harvest time is determined by size, color, and texture since mature fruit will not significantly increase in size if left on the plant to ripen (Sargent, 2000). Traditionally, commercial growers have tar-

Received for publication 9 Sept. 2004. Accepted for publication 3 Dec. 2004. This research was supported in part by the Florida Agricultural Experiment Station, and approved for publication as journal series R-09796. The authors appreciate the assistance of Suzanne Stapleton and Robert C. Hochmuth, North Florida Research and Education Center-Suwannee Valley, for the production of the bell peppers.

${ }^{1}$ Former senior biological scientist, Horticultural Sciences Department.

${ }^{2}$ Graduate research assistant, Department of Food Science and Human Nutrition.

${ }^{3}$ Professor, Horticultural Sciences Department, and corresponding author; e-mail sasa@ufl.edu.

${ }^{4}$ Assistant professor. geted the green bell pepper market, harvesting the fruit upon reaching physiological maturity when the pericarp wall becomes thick and the fruit reaches typical size (USDA, 1989). However, estimating pepper maturity at green stage can be difficult even for fruit with similar physical attributes (Tadesse et al., 2002); under certain conditions green peppers can begin to ripen during shipping. Partially ripened fruit, classified as chocolate or suntan, have lower market values than at the solid color stage.

Bell peppers are increasingly harvested at full color due to growing consumer demand for peppers with improved flavor and nutritional aspects (Frank et al., 2001). Dutch researchers reported that trained taste panelists rated two pepper cultivars at full-red stage higher for sweetness and red bell pepper aroma, while those at green stage were rated higher for bitterness, grassy, and cucumber aroma (Luning et al., 1994). An incentive for growers to harvest ripe peppers is higher market price. For example, in 2003 U.S. wholesale prices at terminal market were typically $50 \%$ to $70 \%$ higher for ripe peppers than for green peppers (Market Information Services, 2003). The high prices have also stimulated greenhouse production of ripe-harvested peppers in nontraditional growing areas such as Florida due to its characteristic warm winters, high light intensity, and loss of farmland in prime growing locations near the coasts (Shaw et al., 2000).
Red and yellow varieties are the most widely sold pepper types, followed by orange and purple. However, ripe peppers are generally more costly for growers to produce than green peppers due to their extended ripening time in the field and the resultant greater likelihood of incurring damage from insects or disease. Ripe peppers are also more susceptible to physical injury during transport and have reduced postharvest shelf life than those harvested at the green stage.

Although nonclimacteric with regard to postharvest respiratory pattern, mature-harvested bell pepper will progress through normal ripening processes to degrade chlorophyll while simultaneously synthesizing a variety of red and yellow carotenoids (Saltveit, 1977). Bell pepper is also a good source of provitamin Acarotenoids and xanthophylls, and numerous studies have focused on improving retention of these compounds during processing and storage (Howard and Hernandez-Brenes, 1998; Markus et al., 1999; Minguez-Mosquera and Hornero-Mendez, 1994; Simonne et al., 1997). Red bell pepper derives its brilliant color from capsanthin, capsorubin, and capsanthin 5, 6-epoxide (Minguez-Mosquera and HorneroMendez, 1994) with concentrations increasing dramatically as the fruit ripens. Bell peppers also contain high concentrations of ascorbic acid ( 0.15 to $2.0 \mathrm{mg} \cdot \mathrm{g}^{-1}$ fresh weight) compared to other fruit and vegetables (Salunkhe, 1997; Simmone et al., 1997; Howard et al., 2000; Yahia et al., 2001). Ascorbic acid development in pepper and other fruit is related to glucose metabolism and light exposure, and concentrations of both ascorbic acid and reducing sugars typically increase as the fruit matures (Mozafar, 1994). Polyphenolics are also an important chemical component in bell pepper and impart functional properties to the plant such as disease resistance and potential health benefits to consumers. Total phenolics, including the flavonoid quercetin, were found to decrease with increased maturity for yellow bell peppers, yet generally increased for other pepper varieties (Howard et al., 2000). Estrada et al. (2000) also demonstrated decreases in free phenolic concentrations in 'Padrón' peppers over five stages of maturity.

Pepper growers could potentially reduce field production costs by hastening the fruit ripening rate on the plant or by harvesting the fruit before attaining full color and completing the ripening process during storage without appreciable loss in quality or phytochemical attributes. Spray application of ethephon [(2chloroethyl) phosphonic acid] prior harvest accelerated field ripening of red pepper types and resulted in higher yields (Cantliffe and Goodwin, 1975). However, ethephon application also induced defoliation, limiting this procedure to once-over harvest for the processing market. This is not compatible for fresh-market bell peppers which require multiple harvests. Ethephon is it not registered for postharvest application to peppers (U.S. EPA, 1988).

Harvested bell peppers are considered mildly responsive to postharvest exposure to ethylene (Ryall and Lipton, 1979). In a preliminary study, we harvested greenhouse-grown 
'Robusta'bell peppers at several ripeness stages ranging from green to full red. When exposed to continuous-flow ethylene $\left(100 \mathrm{~mL} \cdot \mathrm{L}^{-1}\right)$ at $20^{\circ} \mathrm{C}$ and $90 \%$ relative humidity $(\mathrm{RH})$, fruit harvested at $10 \%$ red stage or higher ripened to full-ripe stage faster than those held in ethylene-free air and without significant loss in visual quality. However, those peppers harvested at green stage and continuously exposed to ethylene did not ripen completely before becoming unmarketable (unpublished data). Also we found that accelerated ripening only occurred when the peppers were continuously exposed to ethylene; when ethylene was removed, the ripening rate slowed. Thus, it appeared that the ethylene hastened chlorophyll breakdown during carotenoid synthesis, similar to the process used for commercial degreening of fresh-market citrus, another nonclimacteric fruit (Grierson et al., 1986).

These promising results led to a subsequent, more comprehensive study of two bell pepper cultivars. Red('Triple 4') and yellow ('Kelvin') bell peppers were harvested at $10 \%$ to $30 \%$ color and stored at $20{ }^{\circ} \mathrm{C} / 90 \% \mathrm{RH}$. These fruit also ripened to full color, although exposure to ethylene did not accelerate ripening in either of these varieties (Molinari et al., 2000). Peppers ripened faster off the plant than tagged fruit left to ripen on the plant. Together, these studies suggested that beneficial aspects of ethylene treatment were linked to certain cultivars. Little information is available concerning potential beneficial aspects of ethylene exposure during postharvest ripening of bell pepper, such as color enhancement and subsequent changes to antioxidant phytochemicals.

The objective of this study was to determine the feasibility of using continuous ethylene exposure to accelerate the ripening of bell pepper harvested before full color development. Following development of full-red color, fruit quality was evaluated via selected physicochemical and antioxidant properties. This information could be useful to determine optimal harvest times and postharvest handling practices to develop maximum phytochemical content for bell peppers destined for fresh and process markets.

\section{Materials and Methods}

Production methods, harvest and ripening treatments. The greenhouse variety of 'Robusta' red bell pepper (De Ruiter Seeds, Inc.) was selected for this study since it responded to ethylene in our preliminary study. Plants were grown hydroponically in a greenhouse at the University of Florida's North Florida Research and Education Center-Suwannee Valley (Live Oak, Fla.; $30.18^{\circ} \mathrm{N}, 82.54^{\circ} \mathrm{W}$ ) during the Fall 2001 and Spring 2002 growing season. The plants were grown using lay-flat, perlite bag culture and were trained to the two-stem system (Hochmuth and Hochmuth, 2003). Nutrient solution concentrations were graduated throughout the growing season, with averages during fruit growth period of $\mathrm{N}=125 \mathrm{ppm}, \mathrm{P}=50 \mathrm{ppm}$ and $\mathrm{K}=200 \mathrm{ppm}$. The greenhouse was heated as necessary to maintain ambient temperatures $>10{ }^{\circ} \mathrm{C}$.
Fruit for Expt. 1 were harvested (clipped at stem abscission zone) on 28 Jan. at ripeness stages $<10 \%$ red, $10 \%$ to $30 \%$ red, $30 \%$ to $60 \%$ red, and full red. Fruit for Expt. 2 were harvested on 4 Apr. at $10 \%$ to $30 \%$ red and full red. In both experiments peppers were sorted on the day of harvest for uniform quality. Mean fruit size was $88 \mathrm{~mm}$ (diameter), $67 \mathrm{~mm}$ (length), and $179 \mathrm{~g}$. Peppers were then placed in air or 100 ppm ethylene (continuous-flow chambers) at $20{ }^{\circ} \mathrm{C}$ and $90 \%$ relative humidity $(\mathrm{RH})$ and stored until each fruit reached full-red stage. As each fruit reached full-red color, it was removed from the treatment chamber for analysis. Peppers harvested at full-red stage were analyzed the day of harvest. External color (CIE color values $\left.L^{*}, a^{*}, b^{*}\right)$ was then measured using a chromameter (CR 200 series; Minolta Co., Ltd., Osaka, Japan) on opposite sides of the equator (Expt. 1 only). Illuminant angle was D65 with an 8-mm aperture. Hue angle and chroma values were calculated according to Shewfelt et al. (1988).

Sample preparation and analyses. In both experiments, each fruit was sliced in half axially, and seeds, stem, and calyx were removed. The excised pericarp halves were then packaged in reclosable bags of $0.1 \mathrm{~mm}$ thickness plastic, and frozen to $-30^{\circ} \mathrm{C}$ for up to 6 months until further analyses were conducted. Extracts for soluble solids, titratable acidity and $\mathrm{pH}$ were obtained by homogenizing the fruit halves with a tissuemizer (PT-10; Brinkman Instruments, Westbury, N.Y.) followed by centrifugation at $15,000 g_{\mathrm{n}}$ for $20 \mathrm{~min}$ at $20^{\circ} \mathrm{C}$. The supernatant was filtered through cheesecloth and soluble solids were determined at $20^{\circ} \mathrm{C}$ using a digital Abbe Mark II refractometer (model 10480; Depew, N.Y.). Titratable acidity was determined by potentiometric titration against $0.1 \mathrm{~N} \mathrm{NaOH}$ to $\mathrm{pH} 8.2$ using an automatic titrator (Fisher Titrimeter II, Pittsburgh, Pa.) and expressed in malic acid equivalents, the predominant acid in ripe bell pepper (Luning et al., 1994). Pulp $\mathrm{pH}$ was determined using a digital $\mathrm{pH}$ meter (model 140; Corning).

Total ascorbic acid, the sum of L-ascorbic and dehydroascorbic acid, was quantified by reverse-phase HPLC using modified chromatographic conditions described by Gökmen et al. (2000). Each fruit replicate was homogenized using a tissuemizer (PT-10; Brinkman Instruments, Westbury, N.Y.) for $25 \mathrm{~s}$ at maximum speed in $50-\mathrm{mL}$ screw cap centrifuge tubes containing $30 \mathrm{~mL}$ of $3 \%$ malic acid and the resulting isolate filtered for analysis in triplicate $(15 \mathrm{~g})$. Dithiothreitol $(8 \mathrm{~mm})$ was added to an aliquot of the filtrate as a precolumn reductant and samples kept in the dark for $120 \mathrm{~min}$ to convert dehydroascorbic acid to L-ascorbic acid. Samples were then filtered through a 0.45- $\mu$ m PTFE filter (Whatman, Clifton, N.J.) and analyzed for total ascorbic acid by HPLC. Separation was performed on a Waters 2695 HPLC system using a Supelcosil $4.6 \times 250 \mathrm{~mm}$ LC-18 column(Supelco, Bellefonte, Pa.), $0.2 \mathrm{M}$ $\mathrm{KH}_{2} \mathrm{PO}_{4}(\mathrm{pH} 2.4)$ in the mobile phase at a flow rate of $0.5 \mathrm{~mL} \cdot \mathrm{min}^{-1}$, and $\mathrm{UV}$ detection at 254 $\mathrm{nm}$ using a Waters 996 PDA detector.

For remaining chemical analyses, macerated fruit $(5 \mathrm{~g} / 30 \mathrm{~mL})$ were homogenized in a solution of ethanol and acetone $(1: 1 \mathrm{v} / \mathrm{v})$ to solubilize major phytochemicals including carotenoids, polyphenolics, and ascorbic acid. The resulting extract was filtered through Whatman \#4 filter paper and held in the dark at -20 ${ }^{\circ} \mathrm{C}$ until analysis. This extract was used for the determination of total carotenoids, soluble phenolics, and antioxidant capacity. Carotenoids were determined by recording absorbance values from the two most prevalent spectral bands (452 and $472 \mathrm{~nm}$ ) that corresponded to the red carotenoid capsanthin $(\varepsilon=2,009)$ and yellow carotenoids such as $\beta$-carotene and lutein $(\varepsilon=2,450)$ in a similar manner described by Hornero-Mendez and Minguez-Mosquera (2001). Total soluble phenolics, including contributions from ascorbic acid, were measured using the Folin-Ciocalteu assay (Talcott et al., 2000) with data expressed as gallic acid equivalents. Antioxidant capacity was determined using the oxygen radical absorbance capacity assay using fluorescein as the fluorescent probe and evaluated against a standard of Trolox as described by Talcott et al. (2003). Isolates were diluted 10-fold in $\mathrm{pH} 7.0$ phosphate buffer $(0.75$ $\mathrm{M} \mathrm{K}_{2} \mathrm{HPO}_{4}$ and $0.75 \mathrm{M} \mathrm{NaH}_{2} \mathrm{PO}_{4}, 61.6: 38.9$ $\mathrm{v} / \mathrm{v}$ ) before pipetting triplicate samples into a 96-well microplate with corrections made for background interference due to the phosphate buffer and extraction solvents.

The initial ethanol-acetone extract from each bell pepper isolate was then partitioned into two distinct isolates by isolating lipophilic from hydrophilic compounds by the addition of a known volume of petroleum ether $(1: 3 \mathrm{v} / \mathrm{v})$. Complete partitioning of xanthophylls into petroleum ether was facilitated by the addition of $\mathrm{NaCl}(1 \mathrm{~g})$ before phase separation. An aliquot of the upper petroleum ether phase, containing lipophilic antioxidants, was evaporated under a gentle stream of nitrogen and redissolved in a known volume of acetone and ethanol (1:1 $\mathrm{v} / \mathrm{v}$ ) to maintain solvent consistency. An aliquot of the remaining lower phase, containing hydrophilic antioxidants, was also recovered for subsequent analysis. All three isolates (initial, lipophilic, and hydrophilic) were then evaluated for antioxidant capacity as described. All data except total soluble solids and acids were expressed on a dry weight basis.

Statistical analysis. Each experiment was set up using a randomized complete block design, blocking for ripeness stage at harvest and ripening method. Sample sizes were $n$ $=3$ for all ripeness stages that were stored, and $\mathrm{n}=4$ (Expt. 1) and $\mathrm{n}=7$ (Expt. 2) for full-red harvested peppers. Analysis of variance was conducted using GLM procedure (JMP software Version 5; SAS, 2002), with mean separation performed by the LSD test $(P<0.05)$.

\section{Results and Discussion}

Pepper ripening and quality attributes. Continuous exposure to $100 \mu \mathrm{L} \cdot \mathrm{L}^{-1}$ ethylene significantly accelerated the breakdown of chlorophyll such that these peppers reached fullred stage 3 to $6 \mathrm{~d}$ faster than those stored in air (Table 1). Bell peppers do not ripen uniformly, thus ripening rates were highly variable. Peppers 
that were not completely red after $6 \mathrm{~d}$ storage (air treatment) had good quality; the fruit were very firm, had fresh appearance, stems were green, and were free from shrivel and decay (data not shown). After $10 \mathrm{~d}$ storage, the remaining fruit were moderately firm, had acceptable appearance, stems were yellow-green with slight desiccation, and there was no decay.

Peppers developed typical red color during storage, irrespective of harvest maturity or ripening method, in which values were: $\mathrm{L}^{*}=$ 33.9 to 35.5 ; hue angle $=24.3$ to $29.0^{\circ}$; chroma $=24.2$ to 29.9 (Table 2 ). These were comparable to color values for bell pepper (cv. Triple 4) harvested at full-red stage $\left(\mathrm{L}^{*}=34.2\right.$, hue angle $=25.5^{\circ}$, chroma value $\left.=30.1\right)$ reported previously by Molinari et al. (1999).

Soluble solids content (SSC), total titratable acidity (TTA) and pulp $\mathrm{pH}$ were not affected by harvest maturity or ripening method. SSC ranged from 6.1 to $7.9^{\circ} \mathrm{Brix}$, TTA from 0.22 to $0.34 \mathrm{meq}$ malic acid/g and pulp $\mathrm{pH}$ from 4.9 to 5.1 (Table 3). The higher SSC values for peppers in Expt. 2 can be attributed to more carbohydrate accumulation due to longer daylength, higher ambient temperature and stronger light intensity than for peppers in Expt. 1. Peppers from Expt. 2 underwent primary growth and development during March and April when the daylength ranged from $11 \mathrm{~h} 38 \mathrm{~min}$ to 12 h 34 min, the mean outdoor temperature was $18^{\circ} \mathrm{C}$ and mean maximum/minimum outdoor temperatures were $27 / 10{ }^{\circ} \mathrm{C}$. In contrast, peppers for Expt. 1 underwent growth and development during December and January when the daylength ranged from $10 \mathrm{~h} 13 \mathrm{~min}$ to $10 \mathrm{~h} 40 \mathrm{~min}$, the mean outdoor temperature was $13{ }^{\circ} \mathrm{C}$ and maximum/minimum outdoor temperatures were $20 / 6{ }^{\circ} \mathrm{C}$ (U.S. Naval Observatory, 2003). Minor significant differences in pulp $\mathrm{pH}$ would not cause perceptible flavor differences to consumers.

Phytochemical attributes. Total carotenoids were quantified spectrophotometrically in each fruit at 452 and $472 \mathrm{~nm}$, subjectively corresponding to red (capsanthin) and yellow (ß-carotene) carotenoids, respectively (Minguez-Mosquera and Hornero-Mendez, 1994). Red bell peppers were reported to contain six different carotenoids in concentrations ranging from 1.15 to $4.08 \mu \mathrm{g} \cdot \mathrm{g}^{-1} \mathrm{dry}$ weight, with lutein and capsanthin the predominant compounds in ripe fruit (Russo and Howard, 2002), while an earlier study found that in addition to capsanthin, $\beta$-carotene and violaxanthin were predominant carotenoids (Curl, 1962). In this study, relative changes in concentrations of total carotenoids measured at each wavelength were similar $(r=0.99)$, and indicated no differences due to fruit maturity at harvest or postharvest treatment (Table 4). Carotenoid development occurs as the chloroplast is transformed into chromoplasts during ripening, resulting in novel synthesis of various carotenoids that are not present in green fruit (Hornero-Mendez and Minguez-Mosquera, 2000). Ethylene exposure, despite decreasing the time to reach full red stage, was ineffective at increasing total carotenoids. Data indicate a high degree of variability between bell pepper harvested at $10 \%$ to $30 \%$ color but due to their nonclimacteric nature, the lack of additional carotenoid synthesis with ethylene exposure was a further indication that chlorophyll destruction, and not alteration of carotenoid biosynthetic pathways, was potentially responsible for fruit color development.

Carotenoid development was higher in peppers from Expt. 2, which had more than twice the carotenoid concentration than peppers from Expt. 1. Fruit harvested at 10\% to $30 \%$ red color in Expt. 2 had 79.6 and $64.2 \mathrm{mg} \cdot \mathrm{kg}^{-1}$ capsanthin for air and ethylene-ripened fruit, respectively, while values from Expt. 1 were 41.9 and $28.332 \mathrm{mg} \cdot \mathrm{kg}^{-1}$ for the same respective treatments (Table 4). Russo and Howard (2002) reported that bell peppers grown under greenhouse conditions had higher carotenoid concentrations compared to field-grown fruit, attributable to greater light intensity and lack of stress on the greenhouse-grown plants. Likewise, this study indicated that light intensity might have impacted phytochemical development since daylength was longer, and light intensity and temperature were higher for peppers from Expt. 2. Bell peppers from Expt. 2 that were ripened on the plant also had higher concentrations of carotenoids than those ripened in air or in ethylene.

Table 1. Effect of harvest maturity and postharvest storage treatment on time for 'Robusta' bell peppers to reach full-red color.

\begin{tabular}{llllcc}
\hline & \multicolumn{4}{c}{ Ripening time $(\mathrm{d})^{\mathrm{z}}$} \\
\cline { 2 - 6 } Maturity & \multicolumn{3}{c}{ Expt. 1 } & \multicolumn{3}{c}{ Expt. 2 } \\
\cline { 2 - 5 } at harvest & Air & $\mathrm{C}_{2} \mathrm{H}_{4}$ & Air & $\mathrm{C}_{2} \mathrm{H}_{4}$ \\
\hline$<10 \%$ Red & $11 \mathrm{a}^{y}$ & $6.0 \mathrm{a}^{*}$ & --- & --- \\
$10 \%$ to $30 \%$ Red & $11 \mathrm{a}$ & $4.7 \mathrm{a}^{*}$ & $10.0 \mathrm{a}$ & $6.0 \mathrm{a}^{*}$ \\
$30 \%$ to $60 \%$ Red & $11 \mathrm{a}$ & & $3.0 \mathrm{a}^{*}$ & --- & --- \\
\hline
\end{tabular}

${ }^{7}$ Fruit were stored in air or 100 ppm ethylene at $20^{\circ} \mathrm{C}$ and $90 \%$ RH until full red.

${ }^{y}$ Values with different letters within columns of the same postharvest treatment are significantly different (LSD test, $P<0.05$ ), and indicate the effect of fruit maturity at harvest.

"For each experiment values within rows for each harvest maturity stage are significantly different (LSD test) at $P<0.05$ and indicate the effect of postharvest treatment.

Table 2. Effect of harvest maturity and postharvest storage treatment on external CIE color attributes of 'Robusta' bell peppers at full-red stage (Expt. 1).

\begin{tabular}{|c|c|c|c|c|c|c|}
\hline \multirow{2}{*}{$\begin{array}{l}\text { Maturity } \\
\text { at harvest }\end{array}$} & \multicolumn{2}{|c|}{$\mathrm{L}^{*}$} & \multicolumn{2}{|c|}{ Hue angle $\left(^{\circ}\right)$} & \multicolumn{2}{|c|}{ Chroma value } \\
\hline & Air & $\mathrm{C}_{2} \mathrm{H}_{4}$ & Air & $\mathrm{C}_{2} \mathrm{H}_{4}$ & Air & $\mathrm{C}_{2} \mathrm{H}_{4}$ \\
\hline$<10 \%$ Red & $33.9 \mathrm{~b}^{\mathrm{z}}$ & $\frac{24}{35.5 \mathrm{a}^{\mathrm{y}}}$ & $29.0 \mathrm{a}$ & $\frac{24}{25.4 a^{y}}$ & $24.2 \mathrm{a}$ & $26.0 a^{y}$ \\
\hline $10 \%$ to $30 \% \operatorname{Red}$ & $34.5 \mathrm{a}$ & $36.8 \mathrm{a}$ & $27.3 \mathrm{a}$ & $24.3 \mathrm{a}$ & $25.0 \mathrm{a}$ & $27.8 \mathrm{a}$ \\
\hline $30 \%$ to $60 \% \operatorname{Red}$ & $34.4 \mathrm{a}$ & $33.9 \mathrm{a}$ & $27.9 \mathrm{a}$ & $26.6 \mathrm{a}$ & $24.4 \mathrm{a}$ & $29.9 \mathrm{~b}$ \\
\hline
\end{tabular}

${ }^{2}$ Values with different letters within columns of the same postharvest treatment are significantly different (LSD test, $P<0.05$ ), and indicate the effect of harvest maturity.

yValues within rows for each harvest maturity stage were not significantly different (LSD test, $P<0.05$ ), indicating there was no effect of postharvest treatment.

Table 3. Effect of harvest maturity and postharvest storage treatment on the soluble solids content (SSC), total titratable acidity (TTA), and $\mathrm{pH}$ of 'Robusta' bell peppers at full-red stage.

\begin{tabular}{|c|c|c|c|c|c|c|}
\hline \multirow{2}{*}{$\begin{array}{l}\text { Maturity } \\
\text { at harvest }\end{array}$} & \multicolumn{2}{|c|}{ SSC $\left({ }^{\circ}\right.$ Brix $)$} & \multicolumn{2}{|c|}{$\mathrm{TTA}^{\mathrm{z}}$} & \multicolumn{2}{|c|}{$\mathrm{pH}$} \\
\hline & Air & $\mathrm{C}_{2} \mathrm{H}_{4}$ & Air & $\mathrm{C}_{2} \mathrm{H}_{4}$ & Air & $\mathrm{C}_{2} \mathrm{H}_{4}$ \\
\hline \multicolumn{7}{|l|}{ Expt. 1} \\
\hline$<10 \%$ Red & $6.3 \mathrm{a}^{\mathrm{y}}$ & $5.4 \mathrm{a}^{\mathrm{x}}$ & $0.29 \mathrm{a}$ & $0.34 \mathrm{a}^{\mathrm{x}}$ & $4.9 \mathrm{~b}$ & $5.0 \mathrm{a}^{\mathrm{x}}$ \\
\hline $10 \%$ to $30 \%$ Red & $6.1 \mathrm{a}$ & $6.0 \mathrm{a}$ & $0.29 \mathrm{a}$ & $0.28 \mathrm{a}$ & $5.0 \mathrm{a}$ & $5.0 \mathrm{a}$ \\
\hline $30 \%$ to $60 \% \operatorname{Red}$ & $7.4 \mathrm{a}$ & $6.0 \mathrm{a}$ & $0.28 \mathrm{a}$ & $0.27 \mathrm{a}$ & $5.0 \mathrm{a}$ & $5.0 \mathrm{a}$ \\
\hline Red-ripe & $6.5 \mathrm{a}$ & --- & $0.29 \mathrm{a}$ & --- & $5.0 \mathrm{a}$ & --- \\
\hline \multicolumn{7}{|l|}{ Expt. 2} \\
\hline $10 \%$ to $30 \% \operatorname{Red}$ & $7.1 \mathrm{a}$ & 6.5 & $0.27 \mathrm{a}$ & 0.22 & $5.1 \mathrm{a}$ & 5.0 \\
\hline Red-ripe & $7.9 \mathrm{a}$ & --- & $0.32 \mathrm{a}$ & --- & $5.0 \mathrm{~b}$ & --- \\
\hline
\end{tabular}

${ }^{\mathrm{z}}$ Expressed as meq malic acid/g.

${ }^{y}$ For each experiment, values with different letters within columns of same postharvest treatment are significantly different (LSD test, $P<0.05$ ), and indicate the effect of fruit maturity at harvest.

${ }^{x}$ Values within rows for each harvest maturity stage were not significantly different (LSD test, $P<0.05$ ), indicating there was no effect of postharvest treatment. 
Table 4. Effect of harvest maturity and postharvest storage treatment on individual and total carotenoid contents, ascorbic acid content, total phenolic content, and antioxidant activity of 'Robusta' bell peppers at full-red stage.

\begin{tabular}{|c|c|c|c|c|c|c|c|c|c|c|}
\hline $\begin{array}{l}\text { Maturity } \\
\text { at harvest }\end{array}$ & \multicolumn{2}{|c|}{$\begin{array}{c}\text { Carotenoids } \\
\text { at } 452 \mathrm{~nm} \\
\left(\mathrm{mg} \cdot \mathrm{kg}^{-1} \text { as }\right. \\
\text { capsanthin, dry wt) }\end{array}$} & \multicolumn{2}{|c|}{$\begin{array}{c}\text { Carotenoids } \\
\text { at } 472 \mathrm{~nm} \\
\left(\mathrm{mg} \cdot \mathrm{kg}^{-1} \text { as }\right. \\
\beta \text {-carotene, dry wt) } \\
\end{array}$} & \multicolumn{2}{|c|}{$\begin{array}{c}\text { Ascorbic } \\
\text { acid } \\
\left(\mathrm{mg} \cdot \mathrm{kg}^{-1},\right. \\
\text { dry wt) }\end{array}$} & \multicolumn{2}{|c|}{$\begin{array}{c}\text { Total } \\
\text { soluble } \\
\text { phenolics } \\
\left(\mathrm{mg} \cdot \mathrm{kg}^{-1} \text { as }\right. \\
\text { gallic acid, dry wt }) \\
\end{array}$} & \multicolumn{2}{|c|}{$\begin{array}{l}\text { Antioxidant } \\
\text { capacity } \\
\text { ( } \mu \mathrm{M} \text { Trolox } / \mathrm{g}, \\
\text { dry wt) }\end{array}$} \\
\hline \multicolumn{11}{|l|}{ Expt. 1} \\
\hline$<10 \%$ Red & $32.7 \mathrm{ab}^{\mathrm{z}}$ & $30.4 \mathrm{a}$ & $26.2 \mathrm{ab}$ & $25.2 \mathrm{a}$ & $1,150 \mathrm{a}$ & $749 a^{*}$ & $36.9 \mathrm{ab}$ & $30.4 \mathrm{a}$ & $17.3 \mathrm{~b}$ & $20.2 \mathrm{a}$ \\
\hline $10 \%$ to $30 \% \operatorname{Red}$ & $41.9 \mathrm{a}$ & $28.3 \mathrm{a}^{*}$ & $33.9 \mathrm{a}$ & $23.8 \mathrm{a}$ & $1,000 \mathrm{a}$ & $722 a^{*}$ & $39.9 \mathrm{ab}$ & $30.5 \mathrm{a}$ & $19.3 \mathrm{ab}$ & $19.0 \mathrm{a}$ \\
\hline \multicolumn{11}{|l|}{ Expt. 2} \\
\hline $10 \%$ to $30 \% \operatorname{Red}$ & $79.6 b^{*}$ & $64.2 \mathrm{a}^{*}$ & $99.5 b^{*}$ & $76.5 \mathrm{a}^{*}$ & $2,560 a^{*}$ & $2,000 \mathrm{~b}^{*}$ & $53.8 \mathrm{a}$ & $44.5 \mathrm{~b}$ & $29.2 \mathrm{a}^{*}$ & $26.4 \mathrm{a}$ \\
\hline Full-red & $121.9 \mathrm{a}^{*}$ & --- & $150.5 \mathrm{a}^{*}$ & --- & $2,540 a^{*}$ & --- & $60.0 \mathrm{a}$ & --- & $35.8 \mathrm{a}^{*}$ & --- \\
\hline
\end{tabular}

${ }^{\mathrm{z}}$ For each experiment, values with different letters within columns of same postharvest treatment are significantly different (LSD test, $\left.P<0.05\right)$, and indicate the effect of fruit maturity at harvest.

"Values with a dagger within columns for each harvest maturity stage and experiment are significantly different (LSD test, $P<0.05)$.

capacity $(8.6 \mu \mathrm{M}$ Trolox equivalents $/ \mathrm{g})$ than those from Expt. 1, and were well correlated to both ascorbic acid and soluble phenolics content ( $r=0.84$ and 0.89 , respectively). When fractionated to subsequently determine relative contributions to antioxidant capacity based on polarity, the hydrophilic fraction (polyphenolics and ascorbic acid) contained $88 \% \pm 2.7 \%$ of the total antioxidant activity of the initial isolate (whole fruit) compared to $34 \% \pm 1.0 \%$ for the lipophilic fraction (carotenes and xanthophylls). Capsanthin, the predominant red carotenoid in red bell pepper, was specifically shown to be an effective free radical scavenger even when esterified with fatty acids (Matsufuji et al., 1998), as were the carotenoids in the analyzed isolates.

It was previously reported that flavonoids in the presence of polyphenolics or ascorbic acid might adversely impact antioxidant activity or that prooxidant interactions between ascorbic acid and metal ions may exist (Howard et al., 2000). Since the total antioxidant capacity from each fraction was appreciably higher than the initial stock isolate, there is indication that physical and/or chemical interactions among constituents in these fractions unfavorably impacted radical-scavenging properties. Additionally, since the hydrophilic fraction contained the highest contribution to total antioxidant capacity, the difference in values may reflect the high polarity of the radical system, selectivity against peroxyl radicals, or indicate competition or interactions between antioxidant compounds present.

This study demonstrated that ethylene has potential for use as an effective postharvest treatment to facilitate destruction of chlorophyll and accelerate color change without altering the flavor, content of phytochemicals or antioxidant capacity in red bell pepper, cv. Robusta. Additionally, rates of phytochemical synthesis were not affected by fruit maturity at harvest, although fruit harvested with full color had appreciably higher amounts of phytochemicals and antioxidant capacity. These results indicate that ripening of bell pepper for this cultivar could be accelerated by harvest at partially ripe stage and exposure to ethylene at $20{ }^{\circ} \mathrm{C}$, thereby increasing productivity for growers. Use of vapor barriers during ripening and postripening storage at $10^{\circ} \mathrm{C}$ would likely further extend marketable life.

\section{Literature Cited}

Cantliffe, D.J. and P. Goodwin. 1975. Red color enhancement of pepper fruits by multiple applications of ethephon. J. Amer. Soc. Hort. Sci. 100:157-161.

Curl,A.L. 1962. The carotenoids of red bell peppers. J. Agr. Food Chem. 10:504-509.

Estrada, B., M.A. Bernal, J. Diaz, F. Pomar, and F. Merino. 2000. Fruit development in Capsicum annuum: Changes in capsaicin, lignin, free phenolics, and peroxidase patterns. J. Agr. Food Chem. 48:6234-6239.

Frank, C.A., R.G. Nelson, E.H. Simonne, B.K. Behe and A.H. Simonne. 2001. Consumer preferences for color, price, and vitamin $\mathrm{C}$ content of bell peppers. HortScience 36:795-800.

Gökmen, V., N. Kahraman, N. Demir, and J. Acar. 2000. Enzymatically validated liquid chromatographic method for the determination of ascorbic and dehydroascorbic acids in fruit and vegetables. J. Chrom. A. 881:309-316.

Grierson, W., E. Cohen, and H. Kitagawa. 1986. Fresh citrus fruit. AVI Publ., New York.

Hochmuth, G.J. and R.C. Hochmuth. 2003. Keys to successful tomato and cucumber production in perlite media. Univ. Fla. Coop. Ext. Serv., Gainesville. http://edis.ifas.ufl.edu/HS169.

Hornero-Mendez, D. and I. Minguez-Mosquera. 2000. Xanthophyll esterification accompanying carotenoid overaccumulation in chromoplast of Capsicum annuum ripening fruits is a constitutive process and useful for ripeness index. J. Agr. Food Chem. 48:1617-1622.

Hornero-Mendez, D. and M.I. Minguez-Mosquera. 2001. Rapid spectrophotometric determination of red and yellow isochromic carotenoid fractions in paprika and red pepper oleoresins. J. Agr. Food Chem. 49:3584-3588.

Howard, L.R. and C. Hernandez-Brenes. 1998. Antioxidant content and market quality of jalapeno pepper rings as affected by minimal processing and modified atmosphere packaging. J. Food Qual. 21:317-327.

Howard, L.R., S.T. Talcott, C.H. Brenes, and B. Villalon. 2000. Changes in phytochemical and antioxidant activity of selected pepper cultivars (Capsicum species) as influenced by maturity. J. Agr. Food Chem. 48:1713-1720.

Luning, P.A., R. van der Vuurst de Vries, D. Yuksel, T. Ebenhorst-Seller, H.J. Wichers, and J.P. Roozen. 1994. Combined instrumental and sensory evaluation of flavor of fresh bell peppers (Capsicum аппиит) harvested at three maturation stages.
J. Agr. Food Chem. 42:2855-2861.

Market Information Service (MIS). 2003. University of Florida/Inst. Food \& Agr. Sci., Gainesville. August. http://mis.ifas.ufl.edu/ market/.

Markus, F., H.G. Daood, J. Kapitany, and P.A. Biacs. 1999. Change in the carotenoid and antioxidant content of spice red pepper (paprika) as a function of ripening and some technological factors. J. Agr. Food Chem. 47:100-107.

Matsufuji, H., H. Nakamura, M. Chino, and M. Takeda. 1998. Antioxidant activity of capsanthin and the fatty acid esters in paprika (Capsicum annuит). J. Agr. Food Chem. 46:3468-3472.

Minguez-Mosquera, M. and D. Hornero-Mendez. 1994. Comparative study of the effect of paprika processing on the carotenoids in peppers (Capsicum annuum) of the Bola and Agridulce varieties. J. Agr. Food Chem. 42:1555-1560.

Molinari, A.F., L.R. De Castro, S. Antoniali, P. Pornchaloempong, A.J. Fox, S.A. Sargent, and E.M. Lamb. 2000. The potential for bell pepper harvest before full color development. Proc. Fla. State Hort. Soc. 112.143-146.

Mozafar, A. 1994. Plant vitamins: Agronomic, physiological and nutritional aspects. CRC Press: Boca Ration, FL.

National Agricultural Statistics Service (NASS). 2004. Agricultural Statistics Data Base. Quick Stats. 2002. http://www.nass.usda.gov/fl/rtoc0v. $\mathrm{htm}$.

Osuna-Garcia, J.A., M.M. Wall, and C.A. Waddell. 1998. Endogenous levels of tocopherols and ascorbic acid during fruit ripening of new Mexican-type chile (Capsicum nnuum L.) cultivars. J. Agr. Food Chem. 46:5093-5096.

Russo, V.M. and L.R. Howard. 2002. Carotenoids in pungent and nonpungent peppers at various developmental stages grown in the field and glasshouse. J. Sci. Food Agr. 82:615-624.

Ryall, A.L. and W.J. Lipton. 1979. Handling transportation and storage of fruits and vegetables. p. 587. In Vegetables and Melons. 2nd ed. AVI Publ. Co., Westport, Conn.

Saltveit, Jr., M.E. 1977. Carbon dioxide, ethylene, and color development in ripening mature green bell peppers. J. Amer. Soc. Hort. Sci. 102:523-525.

Salunkhe, D.L. 1997. Storage, processing and nutritional quality of fruits and vegetables. CRC Press, Cleveland, Ohio.

Sargent, S. 2000. Handling Florida vegetables: Pepper.Univ. Fla. Coop. Ext. Serv. IFAS, Gainesville. SS-VEC-927.

SAS Institute, Inc. 2002. JMP Software Version 5. SAS Inst., Cary, N.C.

Shaw, N.L., D.J. Cantliffe, S.T. Rodriguez, and D.M. Spencer. 2000. Beit alpha cucumbers-An 
exciting new greenhouse crop. Proc. Fla. State Hort. Soc. 113:247-253.

Shewfelt, R.L., C.N. Thai, and J.W. Davis. 1988. Prediction of changes in color of tomatoes during ripening at different constant temperatures. J. Food Sci. 53:1433-1437.

Simonne, A.H., E.H. Simonne, R.R. Eitenmiller, H.A. Mills, and N.R. Green. 1997. Ascorbic acid and provitamin A contents in unusually colored bell peppers (Capsicum annuиm L.). J. Food Comp. Anal. 10:299-311.

Tadesse, T., E.W. Hewett, M.A. Nichols, and K.J. Fisher. 2002. Changes in physicochemical attributes of sweet pepper cv. Domino during fruit growth and development. Scientia Hort.

$$
\text { 93:91-103. }
$$

Talcott, S.T., L.R. Howard, and C.H. Brenes. 2000. Antioxidant changes and sensory properties of carrot puree processed with and without periderm tissue. J. Agr. Food Chem. 48:1315-1321.

Talcott, S.T., S.S. Percival, J. Pittet-Moore, and C. Celoria. 2003. Phytochemical composition and antioxidant stability of fortified yellow passion fruit (Passiflora edulis). J. Agr. Food Chem. 51:935-941.

U.S. Department of Agriculture. 1989. United States standards for grades of sweet peppers. USDA. http://www.ams.usda.gov/standards/peperswt. pdf.

U.S. Environmental Protection Agency. 1988.
EPA pesticide fact sheet. Ethephon. Pesticide Mgt. Educ. Progr. Cornell Univ. 29 Sept. 1989. http://pmep.cce.cornell.edu/profiles/herbgrowthreg/dalapon-ethephon/ethephon/herbprof-ethephon.html.

U.S. Naval Observatory. 2003. Data services. Astronomical observations Dept. http://aa.usno.navy. $\mathrm{mil} / \mathrm{data} / \mathrm{docs} / \mathrm{RS}$ OneYear.html.

Yahia, E.M., M. Contreras-Padilla, and G. GonzalezAguilar. 2001. Ascorbic acid content in relation to ascorbic acid oxidase activity and polyamine content in tomato and bell pepper fruits during development, maturation and senescence. Lebensm. Wiss. Technol. 34:452-457. 